BRIEF REPORT

\title{
Detection of Streptobacillus moniliformis in whole blood by real-time PCR and review of clinical cases 2004-2015 in New York State
}

Teresa Passaretti ${ }^{1}$, Kara K. Mitchell ${ }^{1}$, Paula Huth ${ }^{2}$, Glenda Smith ${ }^{3}$, Alexander Davidson ${ }^{4}$, Michelle Dickinson ${ }^{1}$, Anna Kidney ${ }^{1}$, Jocelyn Cole ${ }^{1}$, Nellie Dumas ${ }^{1}$, Elizabeth J. Nazarian ${ }^{1}$, Kimberlee A. Musser ${ }^{1}$

${ }^{1}$ Wadsworth Center, New York State Department of Health, Albany, New York, USA

${ }^{2}$ Bureau of Communicable Disease Control, New York State Department of Health, Albany, New York, USA

${ }^{3}$ New York State Department of Health, Western Regional Office, ${ }^{4}$ New York City Department of Health and Mental Hygiene; New York, USA

\begin{abstract}
Objectives: Early identification of Streptobacillus moniliformis infections that cause rat bite fever (RBF) can be challenging and treatment of these infections is important for the reduction of morbidity and mortality. We report a rapid and sensitive real-time PCR assay for use on whole blood (WB) specimens in less than 3 hrs.

Materials and Methods: We developed a novel two-target real-time PCR assay and assessed sensitivity, specificity, and compared assay performance to $16 \mathrm{~S}$ rDNA analysis. A retrospective study of 9 clinical specimens received from 2004-2015 was performed and available epidemiological data was compiled.

Results: This assay was found to have a limit of detection of $<1$ colony forming unit in WB and to be specific for $S$. moniliformis as well as provide detection of $S$. felis, S. notomytis, and $S$. ratti. Analysis of retrospective specimens determined this assay to be $100 \%$ concordant with $16 \mathrm{~S}$ rDNA analysis and epidemiological data review provided insight into exposures, symptoms and treatment.

Conclusion: This real-time PCR assay represents a valuable tool as it can be performed with instrumentation available in many public health and clinical laboratories, providing results within 3 hours from receiving a WB specimen. Its utilization may improve the detection of RBF and further the understanding of the burden of this disease. J Microbiol Infect Dis 2017; 7(2): 88-92
\end{abstract}

Keywords: Streptobacillus moniliformis, Rat Bite Fever, blood, real-time PCR, clinical

\section{INTRODUCTION}

Streptobacillus moniliformis is a causative agent of rat bite fever (RBF), a rare zoonotic disease. It is a gram-negative, facultative, anaerobic bacillus that can be fastidious and difficult to isolate. Rats are considered the predominant reservoir for $S$. moniliformis, however animals that consume rats may also become infected or colonized $[1,2]$. It is estimated that $50-100 \%$ of wild rats and $10-100 \%$ of domesticated rats are asymptomatically colonized with S. moniliformis [3], and approximately $10 \%$ of rat bites result in infection [4]. Therefore, RBF and rat colonization with $S$. moniliformis represent important public health issues.

Over 200 cases of RBF have been documented in the United States [1], however this is likely a significant under representation of disease burden since RBF is not a mandated nationally reportable disease. Over the past several decades, the likelihood of rodent-human interaction and chances of infection with RBF have increased as rats have gained popularity as pets, as use for reptile food, and wild rats have encroached into populated areas $[5,6]$. More than $50 \%$ of infections occur in children; however laboratory personnel and pet shop employees are other high risk populations $[1,7]$. Infections often result from animal bites, exposure to rat waste, or consumption of contaminated food and drink [8-10]. RBF often has a non-specific clinical presentation with a broad differential diagnosis, and identification and isolation of $S$. moniliformis is not always straightforward $[1,5,11]$ and several new spcies have recently been described and compared to

\footnotetext{
Correspondence: Dr. Kimberlee A. Musser, Wadsworth Center, New York State Department of Health, 120 New Scotland Avenue, Albany, NY 12208, USA, E-mail: kimberlee.musser@health.ny.gov Received: 28 June 2016, Accepted: 09 February 2017

Copyright (C JMID / Journal of Microbiology and Infectious Diseases 2017, All rights reserved
} 
S. moniliformis [12]. Complications from RBF can include endocarditis, myocarditis, meningitis, pneumonia, or sepsis, and when left untreated the mortality rate is approximately $13 \%[13,14]$. Typically patients with RBF are treated with penicillin or tetracyclines $[1,5,15]$. Early identification of $S$. moniliformis is important for implementing immediate patient treatment to prevent severe disease and death [16,17], however few clinical laboratories have the ability to rapidly perform this testing on clinical specimens.

Due to the fastidious nature of this organism, culture from a primary specimen is not always feasible and 16S rDNA analysis (16S) has been the only method suitable for identification at the New York State (NYS) Department of Health Wadsworth Center laboratory. While accurate, $16 S$ is labor intensive and has a long turnaround time, often greater than one week. PCR assays have been utilized $[3,18,19]$ but these require running agarose gels which pose the potential for amplification contamination, and are not permitted as a stand-alone test for laboratory developed tests in New York State [20]. Therefore, we developed a TaqMan® real-time PCR assay that utilizes two fluorescently labeled target-specific probes that detect the 16S rRNA and $g y r B$ genes and allows for rapid detection of $S$. moniliformis from whole blood (WB) in less than 3 hrs.

\section{METHODS}

Whole blood (WB) extraction was performed from $180 \mu \mathrm{l}$ of specimen using the automated bioMerieux NucliSens easyMAG specific B D2 protocol. Prior to extraction, WB samples were seeded with 20 ul of an assay specific inhibition control to assess extraction efficiency and inhibition [21]. Primer and probe sequences were designed to amplify unique sequences within the $16 S$ and $g y r B$ genes of the $S$. moniliformis genome (Table 1). Real-time PCR utilized Quanta Multiplex SuperMix with the following thermal cycling conditions: 1 cycle at $95^{\circ} \mathrm{C}$ for $3 \mathrm{~min}, 40$ cycles at $95^{\circ} \mathrm{C}$ for $15 \mathrm{~s}$ and $60^{\circ} \mathrm{C}$ for $45 \mathrm{~s}$ in an $\mathrm{ABI} 7500$ Real-time PCR instrument (Applied Biosystems). Real-time PCR results were interpreted with a reporting algorithm shown in Table 2, and DNA sequencing was performed on all specimens to confirm the results using 16S rDNA sequence analysis as part of the assay validation.

The specificity of the assay was tested using a panel of 96 organisms including 3 strains of $S$. moniliformis (DSM 12112-type strain, CCUG 14554, and CCUG 31537), 4 other Streptobacillus species (S. felis, $S$. honkongensis, S. notomytis, and $S$. ratti), other organisms which are normal flora as well as those that are found in animal bite wounds and bloodborne infections that can cause disease with similar symptoms to $S$. moniliformis infection. Briefly the panel included Actinomyces neuii, 2 Aeromonas species, Anaplasma phagocytophilum, Babesia microtii, Bacillus cereus, Bartonella vinsonii, 6 Borrelia species, 2 Campylobacter species, Citrobacter freundii, 2 Clostridium species, 2 Corynebacterium species, Eikenella corrodens, Enterobacter cloacae, 2 Enterococcus species, Escherichia coli, Flavobacterium ceti, 5 Fusobacterium species, Haemophilus influenzae, Klebsiella pneumoniae, Legionella pneumophila, 3 Leptotrichia species, Listeria monocytogenes, Micrococcus luteus, Moraxella canis, 4 Mycobacterium species, 4 Neisseria species, 3 Nocardia species, Pasteurella multocida, Peptostreptococcus anaerobius, 3 Prevotella species, Proteus mirabilis, Pseudomonas aeruginosa, Rickettsia rickettsii, Salmonella Enteritidis, Serratia marcescens, 3 Staphylococcus species, Stenotrophomonas maltophilia, 8 Streptococcus species, 3 Treponema species, 3 Vibrio species, and Yersinia enterocolitica.

\section{RESULTS}

As expected in the specificity study, the $3 S$. moniliformis strains tested were positive for both $16 S$ and gyrB targets. The other Streptobacillus species were detected with the $16 S$ target, and three of the four, $S$. felis, $S$. notomytis, and $S$. ratti were also detected with the gyrB target. However, the $C t$ value of the gyrB target was several Cts greater than that seen with the $16 \mathrm{~S}$ target, indicating less specific binding of the primers and probe. The remaining 89 strains all tested negative for both targets demonstrating that the assay has no cross-reactivity with other bacterial species. The limit of detection for the real-time PCR assay was determined to be less than 1 CFU per PCR reaction from WB using a 10-fold dilution series of the DSM $12112 \mathrm{~S}$. 
moniliformis type strain. Our testing algorithm, shown in Table 2, indicates how each real-time PCR result is reported and when further testing is performed. Real-time PCR reporting for either S. moniliformis or Streptobacillus species are reported at the time of testing.

A retrospective analysis of 9 different patient specimens received between 2004 and 2015 was performed. All patients were NYS residents who resided throughout the state, with most of the cases located in the western region of the state $(n=5)$ or within New York City $(n=3)$. Age of patients ranged from 1 year to 74 years, with a median of 28 years. Six of nine $(67 \%)$ patients were male. Detailed epidemiological data was available for six of the nine patients, as shown in Table 3.

Table 1. S. monoliformis real-time PCR primer and probe sequences.

\begin{tabular}{lll}
\hline Target & Name & Sequence (5'-3') \\
\hline 16S $^{\text {a }}$ & Smoni-16S-F & ggttatcccagtctaagaggtaagttct \\
& Smoni-16S-R & agaatgcttaacacatgcaaatctatg \\
& Smoni-16S-P (Texas Red) & cacgttactcaccagtccaccatgtctcttatct \\
\hline gyrB & Smoni-gyrB-F & agtttaaaattccctgaaccacaatt \\
& Smoni-gyrB-R & acttccaaacactcctgaaactatacttg \\
& Smoni-gyrB-P (FAM) & tcacaaactaaggcaaaacttggttcatctgag \\
& Smoni-Bicoid-P (Cy5) & tcgctctgttcataccoggcga \\
\hline Primer Express ${ }^{\text {TM }}$ version 2 software (Applied Biosystems, Foster City, CA) was utilized for the design of all primer and probes. \\
a A primer pair (Smoni-16S-F and Smoni-16S-R) and probe (Smoni-16S-P) were developed to amplify a 112 bp portion of the 1439 \\
bp section of the 16S gene (accession number AB330760)2. \\
b A primer pair (Smoni-gyrB-F and Smoni-gyrB-R) and probe (Smoni-gyrB-P) were developed to amplify a 96 bp portion of the 529 \\
bp gyrB gene (accession number JQ087403) and assess for inhibition with probe (Smoni-Biocoid-P).
\end{tabular}

Table 2: S. monoliformis real-time PCR reporting algorithm.

\begin{tabular}{|c|c|c|}
\hline Result Reported & Real-time PCR result & Additional testing \\
\hline $\begin{array}{l}\text { Streptobacillus moniliformis DNA by } \\
\text { real-time PCR: Detected }\end{array}$ & $\begin{array}{c}16 \mathrm{~S} \text { and } g y r B<37.00 \mathrm{Ct} \text { and within } 4.0 \mathrm{CT} \text { of } \\
\text { each other }\end{array}$ & \\
\hline $\begin{array}{l}\text { Streptobacillus species DNA by } \\
\text { real-time PCR: Detected }\end{array}$ & Either $16 \mathrm{~S}$ or gyrB targets present at $<37.00 \mathrm{Ct}$ & $\begin{array}{l}\text { Reflex testing is performed } \\
\text { to determine the species } \\
\text { present }\end{array}$ \\
\hline $\begin{array}{l}\text { Streptobacillus species DNA by } \\
\text { real-time PCR: Detected }\end{array}$ & $\begin{array}{c}16 \mathrm{~S} \text { or gyrB targets both present at }<37.00 \mathrm{CT} \\
\text { but } g y r B \text { target is }>4 \mathrm{Ct} \text { higher }\end{array}$ & $\begin{array}{l}\text { Reflex testing is performed } \\
\text { to determine the species } \\
\text { present }\end{array}$ \\
\hline $\begin{array}{l}\text { Streptobacillus moniliformis DNA by } \\
\text { real-time PCR: Not detected }\end{array}$ & Both targets $>40.00 \mathrm{Ct}$ & \\
\hline $\begin{array}{l}\text { Streptobacillus moniliformis DNA by } \\
\text { real-time PCR: Inconclusive due to } \\
\text { inhibition }\end{array}$ & $\begin{array}{l}\text { Inhibition control has Ct value }>4.0 \text { from the } \\
\text { seeded negative extraction control, if result } \\
\text { repeats it should be reported as indicated. }\end{array}$ & $\begin{array}{l}\text { Re-extract and retest } \\
\text { sample }\end{array}$ \\
\hline
\end{tabular}

Briefly, patients presented for medical attention on average 5 days from the onset of symptoms (range 2-10 days) and remained hospitalized with an average length of stay of 13 days (range 5-31 days). Data collected from retrospective chart reviews found the most commonly reported symptoms included fever $(100 \%)$, chills $(67 \%)$, rash on extremities $(67 \%)$, vomiting $(50 \%)$, difficulty walking $(50 \%)$, nausea $(50 \%)$, joint effusions (50\%), body/muscle aches (50\%), and joint pain (33\%). Overall, $83 \%$ of patients had confirmed or probable rat exposure in the days or weeks prior to becoming ill. Patients were treated with varied intravenous and/or oral antibiotic regimens, predominantly from the penicillin and tetracycline classes, as indicated in Table 3, and all six fully recovered. Testing performed on all patient samples demonstrated that the $S$. moniliformis real-time PCR assay can detect the organism from WB specimens and culture isolates as shown in Table 3, when compared to $16 \mathrm{~S}$ rDNA sequence analysis the results were $100 \%$ concordant (data not shown). 
Table 3. Epidemiologic data for RBF cases in NYS from 2004-2015

\begin{tabular}{|c|c|c|c|c|c|c|c|c|c|}
\hline No & Country & $\begin{array}{c}\text { Age, } \\
\text { Gender }\end{array}$ & $\begin{array}{l}\text { Specimen } \\
\text { Source }\end{array}$ & $\begin{array}{l}\text { Days } \\
\text { from } \\
\text { symptom } \\
\text { onset to } \\
\text { specimen } \\
\text { collection }\end{array}$ & Symptoms & Treatment & $\begin{array}{c}\text { Exposures } \\
\text { of Interest }\end{array}$ & $\begin{array}{c}16 S \\
\text { Average } \\
\text { Ct }\end{array}$ & $\begin{array}{c}\text { gyrB } \\
\text { Average }\end{array}$ \\
\hline 1 & Niagara & $4, M$ & Abscess & * & * & * & * & 18.17 & 18.96 \\
\hline 2 & Monroe & $1, \mathrm{M}$ & Pustule & * & * & * & * & 18.16 & 17.11 \\
\hline 3 & Broome & $10, F$ & Blood & * & * & * & * & 16.21 & 17.27 \\
\hline 4 & Queens & $23, F$ & Blood & 2 & $\begin{array}{l}\text { Fever, Chills, } \\
\text { Rash, } \\
\text { Nausea, } \\
\text { Vomiting, } \\
\text { Myalgia, } \\
\text { Headache, } \\
\text { Sinus/ear } \\
\text { ache }\end{array}$ & $\begin{array}{l}\text { Ceftriaxone } \\
\text { Amoxicillin }\end{array}$ & $\begin{array}{l}\text { Pet rat } \\
\text { owner }\end{array}$ & 17.08 & 18.13 \\
\hline 5 & Bronx & $72, M$ & Blood & 10 & $\begin{array}{l}\text { Fever, } \\
\text { Nausea, } \\
\text { Vomiting, } \\
\text { Body aches, } \\
\text { Immobility, } \\
\text { Numbness in } \\
\text { extremities, } \\
\text { Weak urine }\end{array}$ & Zosyn Tylenol & None & 17.25 & 18.55 \\
\hline 6 & Queens & $51, M$ & Blood & * & $\begin{array}{l}\text { Fever, Chills, } \\
\text { Body aches, } \\
\text { Difficulty } \\
\text { walking, No } \\
\text { appetite }\end{array}$ & $\begin{array}{c}\text { Benadryl Haldol } \\
\text { Ativan, Simethicone } \\
\text { Lopramide, } \\
\text { Trimethobenzamide, } \\
\text { Ibruprofen Thiamine, } \\
\text { Famotidine } \\
\text { Clonidine }\end{array}$ & $\begin{array}{l}\text { Homeless } \\
\text { with } \\
\text { abrasions, } \\
\text { found ill in } \\
\text { NYC } \\
\text { subway } \\
\text { station }\end{array}$ & ** & ** \\
\hline 7 & Monroe & $74, \mathrm{M}$ & Blood & 2 & $\begin{array}{l}\text { Fever, Chills, } \\
\text { Rash, } \\
\text { Difficulty } \\
\text { walking, } \\
\text { Shortness of } \\
\text { breath, } \\
\text { Lethargy, } \\
\text { Inflammation } \\
\text { of } \\
\text { extremities }\end{array}$ & $\begin{array}{c}\text { Piperacillin- } \\
\text { tazobactam, } \\
\text { Ceftriaxone, } \\
\text { Doxycycline } \\
\text { Bromocriptine, } \\
\text { Amoxicillin Rabies } \\
\text { vaccine }\end{array}$ & Animal bite & 35.14 & 37.04 \\
\hline 8 & Monroe & $28, \mathrm{M}$ & Serum & 8 & $\begin{array}{c}\text { Fever, Chills, } \\
\text { Rash, } \\
\text { Nausea, } \\
\text { Vomiting, } \\
\text { Joint } \\
\text { effusions, } \\
\text { Fatigue, } \\
\text { Diarrhea, } \\
\text { Arthralgia }\end{array}$ & Penicillin, Amoxicillin & $\begin{array}{l}\text { Pet rat } \\
\text { owner }\end{array}$ & 37.7 & 38.76 \\
\hline 9 & Monroe & $52, \mathrm{~F}$ & Blood & 5 & $\begin{array}{l}\text { Fever, Rash, } \\
\text { Pain in } \\
\text { extremities, } \\
\text { Joint pain }\end{array}$ & $\begin{array}{l}\text { Ceftriaxone, } \\
\text { Doxycycline }\end{array}$ & $\begin{array}{l}\text { Pet rat } \\
\text { owner }\end{array}$ & 36.22 & 38.58 \\
\hline
\end{tabular}

** Sample submitted as an isolate and was identified with MALDI-TOF Mass Spectrometry.

\section{DISCUSSION}

In conclusion, this study describes a highly sensitive and specific real-time PCR assay for detection of $S$. moniliformis that meets the regulatory requirements for diagnostic testing in NYS [20]. It offers a rapid, accurate, and cost effective alternative to $16 \mathrm{~S}$ analysis and conventional culture methods for identification.
Since culture of this organism from a primary specimen is not always successful this method also serves as a practical alternative to other methods of identification, such as MALDI-TOF MS. The six case studies presented here describe RBF cases from across NYS with detailed patient symptomology, exposure, and treatment information. This study highlights the 
need for detection of $S$. moniliformis as it is believed that known cases in the US represent a significant underestimation as neither the disease nor the isolation of the bacteria as reportable to health departments [1].

Additionally, early identification of $S$. moniliformis is important for implementing timely patient treatment to prevent severe disease [1] and identification of other species of Streptobacillus may help to further our understanding of the contribution of these species as a public health threat [12]. This realtime PCR represents a valuable tool since it can be performed with instrumentation readily available in most public health and many clinical laboratories, providing results within 3 hours from receiving a WB specimen.

\section{ACKNOWLEDGEMENT}

Funding: Source of funding- New York State

Competing interests: None to declare.

\section{REFERENCES}

1. Elliott SP. Rat bite fever and Streptobacillus moniliformis. Clin Microbiol Rev 2007; 20:1322.

2. Wouters EG, Ho HT, Lipman LJ, Gaastra W. Dogs as vectors of Streptobacillus moniliformis infection? Vet Microbiol 2008; 128:419-22.

3. Boot R, Oosterhuis A, Thuis HC. PCR for the detection of Streptobacillus moniliformis. Lab Animal 2002; 36:200-208.

4. Khatchadourian $K$, Ovetchkine $P$, Minodier $\mathrm{P}$, Lamarre $\mathrm{V}$, Lebel $\mathrm{MH}$, Tapiero $\mathrm{B}$. The rise of the rats: A growing paediatric issue. Paediatr \& Child Health 2010; 15:131-134.

5. Graves MH, Janda JM. Rat-bite fever (Streptobacillus moniliformis): a potential emerging disease. Int J Infect Dis 2001; 5:151-5.

6. Hagelskjaer L, Sorensen I, Randers E. Streptobacillus moniliformis infection: 2 cases and a literature review. Scan $\mathrm{J}$ infect Dis 1998; 30:309-311.

7. Anderson LC, Leary SL, Manning PJ. Ratbite fever in animal research laboratory personnel. Lab Animal Sci 1983; 33:292-294.

8. Andre JM, Freydiere AM, Benito Y, et al. Rat bite fever caused by Streptobacillus moniliformis in a child: human infection and rat carriage diagnosed by PCR. Journal of clinical pathology. 2005; 58:1215-6.

9. Albedwawi S, LeBlanc C, Shaw A, Slinger RW. A teenager with fever, rash and arthritis. Can Med Assoc J 2006; 175:354.

10. Gaastra W, Boot R, Ho HT, Lipman LJ. Rat bite fever. Vet Microbiol 2009; 133:211-228.

11. Stehle P, Dubuis O, So A, Dudler J. Rat bite fever without fever. Annals of the rheumatic diseases. 2003; 62:894-896.

12. Eisenberg T, Nicklas W, Mauder N, et al. Phenotypic and Genotypic Characteristics of Members of the Genus Streptobacillus. PLoS ONE. 2015; 10(8): e0134312.

13. Madhubashini M, George $S$, Chandrasekaran S. Streptobacillus moniliformis endocarditis: case report and review of literature. Indian heart journal. 2013; 65:442-6

14. Rupp ME. Streptobacillus moniliformis endocarditis: case report and review. Clinical infectious diseases : an official publication of the Infectious Diseases Society of America. 1992; 14:769-72.

15. Freels LK, Elliott SP. Rat bite fever: three case reports and a literature review. Clin Pediatr 2004;43:291-5.

16. Adam JK, Varan AK, Pong AL, McDonald EC. MMWR 2014; 63:1210-1211.

17. Banerjee $P$, Ali Z, Fowler DR. Rat bite fever, a fatal case of Streptobacillus moniliformis infection in a 14-month-old boy. J Forens Sci 2011; 56:531-3.

18. Nakagomi D, Deguchi N, Yagasaki A, et al. Rat-bite fever identified by polymerase chain reaction detection of Streptobacillus moniliformis DNA. J Dermatol 2008; 35:667670.

19. Berger C, Altwegg M, Meyer A, Nadal D. Broad range polymerase chain reaction for diagnosis of rat-bite fever caused by Streptobacillus moniliformis. Pediatr Inf Dis J 2001; 20:1181-2.

20. Musser KA. Validation of New Molecular Tests for Microbiological Testing of Clinical Specimens. Clin Microbiol Newslet 2009; 31:185-192.

21. Nazarian EJ, Bopp DJ, Saylors A, Limberger RJ, Musser KA. Design and implementation of a protocol for the detection of Legionella in clinical and environmental samples. Diagn Microbiol Inf Dis 2008; 62:125-32. 